\title{
INVESTMENT ARBITRATION BAGI NEGARA BERKEMBANG DAN TERBELAKANG
}

\author{
Sefriani \\ Fakultas Hukum Universitas Islam Indonesia \\ Email: sefri ani@yahoo.com
}

\begin{abstract}
The main problem statements in this research is what factors cause almost no developing countries and last developing countries win before the investment arbitration. This thesis employs normative method of research with qualitative analysis. The result of this thesis show that BIT is the main factor caused it. The BIT contain vagueness term, arbitrator of investment arbitration do open ended interpretation toward the term, and cause damage to developing countries and last developing countries. The solution for this phenomena is that developing countries as capital importer should be aware, careful and has equal bargaining power in the process of adoption of BIT with developed countries as capital exporter. Equal bargaining power can be achieved if developing countries has independency, have no dependency in any matters such as economic politics, security and defence, etc
\end{abstract}

Keywords: investment arbitration, Bilateral investment treaty, dispute resolution

\begin{abstract}
Abstrak
Masalah utama yang diteliti dalam penelitian ini adalah faktor-faktor penyebab kekalahan negara berkembang dan terbelakang di depan forum investment arbitration. Penelitian ini merupakan penelitian hukum normatif, jenis data yang digunakan adalah data sekunder yang terdiri atas bahan hukum primer, sekunder dan tersier. Pendekatan penelitian yang digunakan adalah pendekatan perundang-undangan, histori, dan konsep. Teknik analisis yang dilakukan adalah analisis kualitatif. Hasil penelitian disajikan secara deskriptif analitis. Hasil penelitian menunjukkan bahwa BIT menjadi factor utama penyebab semuanya itu. BIT berisikan ketentuan-ketentuan yang sangat berpihak pada kepentingan negara eksportir modal. Banyak ketentuan yang multitafsir dan kemudian diinterpretasikan secara sangat luas oleh arbitrator di forum investment arbitration untuk kepentingan negara maju, negara eksportir modal. Solusi untuk mengatasi hak tersebut adalah bahwa negara berkembang harus sadar, cermat dan memiliki posisi tawar yang seimbang dengan negara maju dalam penyusunan BIT. Semua ini dapat diraih apabila negara berkembang memiliki independensi, tidak memiliki ketergantungan pada segala bidang seperti, ekonomi, politik juga pertahanan keamanan pada negara eksportir modal.
\end{abstract}

Kata Kunci: Arbitrase investasi, perjanjian bilateral investasi, penyelesaian sengketa

\section{A. Pendahuluan}

Masih jelas dalam ingatan, tahun 2000, Indonesia, dalam hal ini adalah Pertamina dan PLN, kalah dalam sidang arbitrase di Swiss. Putusan Arbitrase Jenewa, Swiss, tertanggal 18 Desember 2000 memerintahkan Pertamina dan PLN membayar ganti rugi kepada Karaha bodas Company $(\mathrm{KBC})$, perusahaan yang berkedudukan di Cyman Island yang dimiliki oleh investor Amerika Serikat, KBC sebesar US\$270,000,000 (Hikmahanto Juwono, 2008:69-70). Ketika Pertamina tidak mau membayar dengan sukarela ganti rugi tersebut Karaha Bodas mencari upaya paksa penyitaan aset-aset pertamina yang ada di luar negeri, antara lain di Pengadilan Distrik Texas, dan Columbia (Karaha Bodas Company LLC Petitioner v Perusahaan Pertambangan Minyak dan Gas bumi Negara, respondent No. Clv.A.H 01-0634. (264 F.Supp.2d 470), Court of Final Appeal Final Appeal No 6 of 2008 (Civil) CFA FACv 6/2008 (2008 WL 4928699 (CFA), [2008] HKEC 2063).

Kasus berikutnya juga dialami Pertamina ketika pada tahun 2008 International chamber of commerce (ICC), lembaga arbitrase internasional yang berkedudukan di Paris memutuskan bahwa 
Pertamina harus membayar kerugian kepada PT Lirik sebesar AS\$34,172 juta (sekitar Rp346,8 miliar) dan biaya perkara arbitrase sebesar AS\$323.250 (sekitar Rp3,2 miliar). Majelis Hakim Arbitrase ICC juga menghukum Pertamina membayar bunga enem persen $(6 \%)$ setiap tahun dari jumlah ganti rugi sejak Final Award (putusan akhir) dijatuhkan hingga putusan dieksekusi (http:// hukumonline.com/berita/baca/hol22092/; Mieke Komar Kantaadmadja , 2011:6).

Dua kasus di atas adalah contoh putusan yang diberikan oleh international investment arbitration yang mengadili sengketa akibat investasi antara negara tempat investasi dilaksanakan dengan investor asing. Ganti rugi yang wajib dibayarkan oleh Indonesia dalam dua kasus di atas tentu saja sangat signifikan. Oleh karenanya, pihak Indonesia, dalam hal ini Pertamina berupaya keras melakukan perlawanan dengan berbagai upaya yang ada.

Meskipun ada sedikit perbedaan di sana-sini terkait laporan-laporan tahunan yang diberikan antara lain oleh UNcTAd; World Bank; penelitian yang dilakukan International non government Organization (INgO); dan tulisan para pakar hukum, Susan D Franck menyimpulkan bahwa kurang lebih $90 \%$ tergugat (respondent) dalam arbitrase investasi adalah negara berkembang dan terbelakang. Argentina adalah yang paling banyak digugat di depan arbitrase. Dalam semua kasus yang menjadikan negara tuan rumah sebagai responden tersebut hampir semuanya dimenangkan oleh pihak investor asing termasuk kasus karaha Bodas dan PT Lirik Petroleum (Susan D Franck, 2007:11).

Sebagian besar kasus sengketa investasi diadili di depan forum IcSId yang menangani hampir $70 \%$ kasus, disusul berturut-turut UNcITrAL, Stockholm chamber of commerce (Scc), dan International chamber of commerce (ICC) (http://www.unctad.org/en/docs/webiteiit 20092:3). IcSId disukai karena hubungannya dengan World Bank yang dianggap dapat memberikan jaminan lebih besar pelaksanaan putusannya (Susan D Franck, 2007:13).

Data menunjukkan $76 \%$ pihak bersengketa menyukai arbitrase institusional daripada arbitrase adhoc untuk menyelesaikan sengketa mereka dengan alasan reputasi, pemahaman dan kebiasaan mereka. Adapun arbitrase adhoc dipilih dengan pertimbangan biaya yang lebih sedikit dan kontrol yang lebih besar dari pihak yang bersengketa (Dough Sperry:2011:362). Data juga menunjukkan bahwa bidang pelayanan publik yang paling banyak disengketakan. Dalam laporannya, UNcTAd menyampaikan bahwa lebih dari $42 \%$ sengketa investasi di bidang jasa termasuk di dalamnya distribusi listrik, telekomunikasi, instrumen hutang, distribusi air dan managemen pengelolaan sampah. Berikutnya $(29 \%)$ adalah menyangkut sengketa bahan tambang, minyak bumi dan gas (http://www. unctad.org/en/docs/webiteiit20092:4). Adapun laporan NGO menyebutkan bahwa $70 \%$ kasus IcSId adalah terkait investasi swasta di bidang pelayanan publik seperti air, telekomunikasi atau investasi di bidang pertambangan (Susan D Franck:2007:15).

Menanggapi putusan-putusan yang di keluarkan berbagai lembaga arbitrase internasional dalam sengketa investasi tersebut, dalam tulisannya berjudul Who Wins and Who Loses in Investment Arbitration? Are Investors and Host States on a Level playing Field? Nathalie Bernasconi dan Osterwalder menyampaikan bahwa negara tuan rumah tidak pernah menang di depan arbitrase investasi (Nathalie Bernasconi \& Osterwalder:2005: :69). Tidak jauh berbeda, Emad Mekay menyimpulkan bahwa negaranegara miskin membayar terlalu mahal untuk kesepakatan investasi yang dibuatnya (Emad Mekay, 2004).

Lebih lanjut, Presiden Bolibia, Even Evo Morales, dalam salah satu pidatonya menyampaikan bahwa investor asing yang merupakan perusahaan transnasional selalu menang, negara-negara Amerika Latin tidak pernah menang dalam berarbitrase. Hugo Chavez sebagaimana yang dikutip oleh Susan menyatakan bahwa "I didn't know that [IcSId] existed, but we're pulling out anyway (Susan.d Franck, 2011:17). Masih banyak komentar-komentar lain yang intinya menyatakan bahwa investment arbitration atau yang sering disebut juga sebagai state-investor arbitration tidak demokratis dan diragukan kredibilitasnya (Susan.D Franck, 2011:17).

Untuk menunjukkan kekecewaannya pada lembaga arbitrase ini beberapa negara Amerika Latin bahkan menyatakan mundur dari kepersertaannya dalam International centre for Investment dispute/ICSID (Susan.D Franck, 2011:17).

Berangkat dari kekalahan-kekalahan negara berkembang dan terbelakang dalam kasus-kasus sengketa investasi di depan forum arbitrase internasional tersebut, di samping berbagai kekecewaan, keputusasaan, dan komentarkomentar miring tentang lembaga tersebut, tulisan ini mengkaji secara lebih mendalam tentang lembaga arbitrase investasi atau state-investor arbitration, serta faktor-faktor yang menyebabkan 
negara berkembang dan terbelakang selalu kalah di forum investment arbitration.

\section{B. Metode Penelitian}

Penelitian ini merupakan penelitian hukum normatif, jenis data yang digunakan adalah data sekunder yang terdiri atas bahan hukum primer, sekunder dan tersier. Bahan hukum primer antara lain New York Convention 1958 tentang Pengakuan dan Pelaksanaan Putusan Arbitrase Asing, Konvensi IcSId 1965 tentang International centre for Investment dispute, Bilateral Investment Treaty (BIT). Bahan hukum sekunder berupa hasil penelitian, tulisan dan pendapat para pakar hukum internasional terkait masalah investment arbitration. Adapun bahan tersier berupa kamus dan ensiklopedi. Bahanbahan hukum tersebut diperoleh dengan library research. Pendekatan penelitian yang digunakan adalah pendekatan perundandangan, histori, dan konsep. Teknik analisis yang dilakukan adalah analisis kualitatif. Hasil penelitian disajikan secara deskriptif analitis.

\section{Hasil Penelitian dan Pembahasan}

\section{Eksistensi Investment Arbitration}

Arbitrase Investasi (investment arbitration), yaitu arbitrase yang menangani sengketa penanaman modal atau investasi. Arbitrase ini sering disebut juga dengan istilah investment treaty arbitration atau juga state-investor arbitration. Ketiga istilah ini didefinisikan sebagai arbitrase yang mengadili sengketa masalah investasi dengan para pihaknya negara (host state) melawan investor asing mengenai hak dan kewajiban yang muncul dari perjanjian investasi internasional. Arbitrase IcSId merupakan salah satu lembaga yang kewenangannya khusus menangani masalah sengketa investasi. Selain IcSId sengketa investasi juga dapat diajukan ke berbagai arbitrase internahanasional lainnya baik permanent maupun ad hoc, meskipun kewenangannya tidak spesifik masalah investasi seperti halnya IcSId (Stephan W Schill, 2010 : 401). Berbagai lembaga yang dimaksud misalnya International chamber of commerce (ICC), Stockholm chamber of commerce (ScC), UNcITrAL, dan lain-lain.

Investment arbitration sesungguhnya merupakan bagian Arbitrase Komersial Internasional (AKI). AKI merupakan alternatif penyelesaian sengketa Internasional yang banyak dipilih oleh para pihak bersengketa karena memiliki berbagai kelebihan dibanding penyelesaian sengketa melalui jalur pengadilan. Kelebihan yang dimiliki lembaga ini apabila dibandingkan dengan pengadilan nasional antara lain adalah penyelesaian sengketa yang lebih cepat, sehingga hemat waktu, tenaga dan biaya, lebih profesional karena ditangani oleh orang-orang yang kompeten di bidangnya, bersifat final dan mengikat; proses beracara tidak begitu formal dan fleksibel. Kelebihan lain yang menjadi daya tarik penggunaan arbitrase adalah terjaminnya proses kerahasiaan berperkara karena tidak ada kewajiban mempublikasikan putusan seperti dalam putusan pengadilan nasional. Di samping itu, hal yang tidak kalah menarik adalah para pihak diberi kesempatan memilih arbitrator. Kelebihan lain, tidak adanya pilihan hukum yang kaku dan tidak ditentukan sebelumnya. Penyelesaian sengketa melalui arbitrase ini tidak harus selalu diselesaikan menurut proses hukum tertentu saja, tetapi dimungkinkan suatu penyelesaian secara kompromi di antara para pihak (Huala Adolf, 1991:12-15). Masih terkait kelebihan arbitrase cukup penting mencatat pernyataan Pieter Sanders yang dikutip oleh Julian DM Lew bahwa: arbitration...is a service to the international community looking for speedy, efficient, fair and, if possible, less exspensive solution for disputes that may always arise out of international relations. (Julian DM Lew:1987:11)

Dibalik keunggulan-keunggulan tersebut sesungguhnya lembaga arbitrase juga memiliki berbagai kelemahan. Tidak selamanya berarbitrase cepat dan murah. Penyelesaian kasus Wisma Kartika misalnya memakan waktu 12 tahun dan menghabiskan biaya yang sangat besar. Tidak selamanya arbitrase memberikan keuntungan kepada kedua belah pihak berdsarkan prinsip win-win solution sebagaimana yang dikampanyaken oleh negara-negara maju. Investment arbitration adalah salah satu bentuk penyelesaian sengketa melalui lembaga arbitrase yang menuai banyak protes khususnya dari negara berkembang dan terbelakang.

Hubungan antara investment arbitration dan AKI dapat digambarkan sebagai berikut. AKI dapat dibedakan dua yaitu arbitrase yang berdasarkan kontrak (contract-based arbitration) dan arbitrase yang berdasarkan perjanjian (treaty-based arbitration). Pada arbitrase tipe pertama para pihak yang bersengketa adalah private commercial 
parties, sering disebut dengan purely commercial arbitration. Adapun arbitrase tipe kedua yang bersengketa adalah foreign private investor dengan negara berdaulat (host state) (Dough Sperry, 2011:362). Bentuk arbitrase tipe kedua inilah yang sering disebut dengan istilah arbitrase investasi atau state-investor arbitration. Namun demikian, sebagai catatan, meskipun tipe ini disebut purely komersial arbitration, kedua belah pihak adalah pihak swasta, namun tidak berarti bahwa negara tidak dapat menjadi pihak dalam arbitrase tipe pertama ini. Hal ini dikarenakan negara dapat melakukan berbagai aktifitas komersial dengan pihak swasta asing melalui berbagai badan hukum atau perusahaan yang keseluruhan atau sebagain sahamnya dimiliki oleh negara. Meskipun badan hukum atau perusahaan milik negara ini berbadan hukum terpisah dari negara namun tidak bisa menutupi fakta bahwa badan hukum atau perusahaan tersebut adalah milik negara, sehingga apa yang terjadi pada badan hukum atau perusahaan tersebut sedikit banyak juga akan melibatkan negara serta akan berdampak pada negara.

Sesungguhnya AKI tipe kedua ini belum memiliki istilah baku. Dalam praktek arbitrase tipe kedua ini memiliki berbagai istilah seperti arbitrase investasi (investment arbitration) atau arbitrase tentang perjanjian investasi (investment treaty arbitration) atau arbitrase negarainvestor (state- investor arbitration). Adapun AFM Maniruzzaman tidak menggunakan istilah investment arbitration melainkan Arbitrations concerning International Economic development Agreements (IEDA) yaitu arbitrase yang menangani sengketa yang muncul dari perjanjian pembangunan ekonomi Internasional (AFM Maniruzzaman, 2005:263). Istilah ini digunakan mengingat bahwa investasi terkait erat dengan pembangunan ekonomi host state. Investasi diatur dalam perjanjian tentang pembangunan ekonomi (economic development agreement).

Sumber hukum AKI tipe pertama adalah privat contract antara kedua belah pihak yang bersengketa. Para pihak dapat memilih hukum acara dan hukum materiilnya. Dalam kondisi tertentu arbitrase tipe ini memungkinkan dilakukannya banding ke pengadilan nasional. Pelaksanaan putusan merujuk pada Konvensi New York 1958 tentang pengakuan dan pelaksanaan putusan arbitrase asing. Adapun
Penyelenggaraan arbitrase tipe kedua adalah berdasarkan hukum internasional publik, pelanggaran kewajiban perjanjian internasional. Melalui klausul arbitrase dalam perjanjian investasi (investment treaty) seperti Bilateral Investment Treaty (BIT), investor asing dapat mengajukan gugatannya langsung pada arbitrase, tanpa harus diwakili negara asalnya, melawan negara tuan rumah yang dipandang melanggar hak-haknya yang di dapat dari investment treaty baik bilateral maupun multilateral investment treaty (AFM Maniruzzaman, 2005:263).

\section{Bilateral Investment Treaty dalam Investment Arbitration}

Terkait pelaksanaan putusan arbitrase yang melibatkan negara sebagai salah satu pihak, investment arbitration lebih banyak mengundang permasalahan ketidakadilan dibandingkan dengan contract-investor arbitration. Investment arbitration tidak hanya menyelesaikan masalah hak dan kewajiban para pihak yang diatur dalam kontrak antara kedua belah pihak yang bersengketa saja tetapi juga menyangkut penerapan perjanjian internasional publik baik yang bentuknya bilateral maupun multilateral yang melibatkan negara pengimpor modal (host state) dan negara pengekspor modal (home state) mengenai perlindungan investasi. Masalah ketidakadilan muncul dikarenakan posisi tawar yang tidak seimbang antara negara pengekspor modal (mayoritas negara maju) dan negara pengimpor modal (negara berkembang dan terbelakang). Posisi tawar yang tidak seimbang dimanfaatkan oleh negara pengekspor modal dalam proses pembuatan Bilateral Investment Treaty (BIT) sehingga isi BIT tersebut sangat berpihak pada kepentingan negara pengekspor modal.

BIT saat ini merupakan cara yang dianggap paling populer bagi negaranegara pengekspor modal untuk melindungi kepentingan warganya yang menanamkan modalnya di negara pengimpor modal. Seiring dengan globalisasi ekonomi, pertumbuhan BIT sangatlah fantastis. Pada akhir 1950-an hanya ada dua $B I T$, akhir 1960 -an menjadi $48 B I T$, akhir 1970-an menjadi $69 B I T$, akhir 1980-an ada 102 BIT, akhir 1990-an 173 BIT (Calvin A. Hamilton, \& Paula I. Rochwerger, 2005:2), dan angka ini melonjak drastis ketika sampai dengan 2009 terdapat lebih 2600 BIT (Damon vis Dunbar and Henrique Suzy Nikeima, 2009:15). BIT adalah perjanjian 
antara dua negara yang memberikan hak pada investor masing-masing ketika berinvestasi di wilayah negara lain dalam perjanjian tersebut. Mayoritas BIT adalah antara negara maju dan berkembang. Sangatlah sedikit BIT yang dibuat antara sesama negara maju dengan alasan antar mereka telah memiliki mekanisme dan pengawasan sendiri yaitu melalui OECD (Calvin A. Hamilton, \& Paula I. Rochwerger, 2005:2) .

Di samping BIT, Multilateral Investment Treaty (MIT) juga merupakan sumber yang penting bagi investment treaty arbitration. Beberapa contoh MIT yang ada antara lain adalah North American Free Trade Agreement (NAFTA) yang beranggotakan antara lain Mexico, Canada dan USA; the Energy charter Treaty (ECT) yang beranggotakan antara lain negara-negara Eropa Barat, Tengah dan Timur, termasuk bekas negara Uni Soviet, Jepang dan Australia; the Mercando comun del Sur (MErcOSUr) yang beranggotakan antara lain Argentina, Brazil, Paraguay, dan Uruguay; cartagena Free Trade Area yang beranggotakan Columbia, Mexico dan venezuela; the Association of South East Asian Nations (ASEAN) dan the dominican republic-central American-United States Free Trade Agreement (dr-cAFTA) yang beranggotakan antara lain Columbia, Mexico dan venezuela. Perjanjian-perjanjian tersebut juga menyediakan arbitrase komersial internasional untuk menyelesaikan sengketa para pihak. (Dough Sperry, 2011:363).

Dibandingkan BIT, MIT lebih bisa memberikan keseimbangan dan keadilan pada host state. Keterlibatan banyak negara dalam pembuatan perjanjian itu akan menyulitkan keinginan suatu negara yang ingin mendapatkan keuntungan secara tidak adil dari perumusan perjanjian investasi. Namun demikian, di sisi lain keterlibatan banyak negara dalam proses negosiasi cenderung lebih menyulitkan proses penerimaan perjanjian tersebut karena masing-masing memiliki kepentingan yang berbeda (Calvin A. Hamilton, \& Paula I. Rochwerger, 2005 :7)

Munculnya berbagai perjanjian internasional baik bilateral maupun multilateral tentang perlindungan investor asing tidak dapat dilepaskan dari sejarah hukum investasi internasional. Di era kolonial masalah investasi sengketa investasi diselesaikan melalui gun boat diplomacy. Sengketa diselesaikan menggunakan diplomasi di bawah todongan senjata (Sornarajah, 2010, 78). Hukum internasional yang mengatur masalah investasi saat itu sangatlah minim. (Ibironke T Odumosu, 2007:262), di era ini hukum penyelesaian sengketa didominasi hubungan negara dan negara. Negaranegara yang saat ini dikenal sebagai negara berkembang tidak dilibatkan dalam proses pembuatan hukum tersebut karena statusnya saat itu bukanlah sebagai subyek hukum internasional. Kondisi inilah yang menjadikan hukum internasional tentang intervensi dianggap tidak berpihak pada kelompok negara ini dan tidak heran pula apabila dalam perkembangannya lahirlah Doktrin calvo yang lahir dari pemikiran pemimpin negara Amerika Latin. Doktrin ini menetapkan bahwa host state memiliki yurisdiksi menyelesaikan sengketa investasi asing. Negara-negara Amerika Latin sebenarnya tidaklah sendiri dalam mengadopsi Doktrin calvo. Sebelumnya banyak negara maju sudah menerapkan ketentuan sejenis, yang nampak dalam the Energy charter Treaty, yang isinya sama dengan Doktrin calvo tetapi mengecualikan sengketa tentang investasi gas dan minyak dari arbitrase internasional (Thomas Walde, 1998:221)

BIT dimaksudkan untuk melindungi investor dari resiko politik perubahan kebijakan negara tuan rumah yang dapat merubah iklim investasi dan berdampak buruk pada investasinya. Dengan kata lain, di bawah payung $B I T$, investor yang umumnya adalah perusahaan transnasional dari negara maju (home state) diberikan perlindungan dari perlakuan-perlakuan tertentu negara tuan rumah yang berpotensi merugikan kepentingannya.. Memajukan investasi, liberalisasi dan perlindungan investasi adalah tujuan utama BIT. Keberadaan BIT tidak dapat dilepaskan dari sejarah hukum investasi ketika beberapa negara tuan rumah khususnya negara yang pernah dijajah mengambil alih aset perusahaan milik warga negara bekas negara penjajahmya tanpa memberikan ganti rugi.

Perlindungan ini dirasakan penting menurut negara maju terkait masalah expropriation, local bias dari host state court, pengadilan lokal yang tidak efisien, juga imunitas negara yang digunakan pemerintah lokal. Meskipun BIT bervariasi tetapi pada umumnya memberikan perlindungan yang sejenis seperti "fair and equitable treatment", "full protection and security", "protection 
against uncompensated expropriation or naturalisation", juga menyediakan hak bagi investor untuk "free transfer of funds" dan mendapatkan perlakuan yang tidak melanggar "national treatment dan mostfavoured-nation treatment" (Dough Sperry, 2011:363).

$B I T$ juga selalu memasukkan indirect expropriation atau tindakan-tindakan yang menimbulkan efek serupa (Joachim Karl, 2009:231) atau yang sering disebut sebagai creeping expropriation atau regulatory expropriation ketika aset investor mengalami devaluasi melalui cara-cara diluar direct expropriatio (Alexis Blane, 2009 : 463). Hal lain adalah bahwa BIT membatasi kewenangan negara tuan rumah menerbitkan aturan yang berpotensi merugikan investor seperti kewajiban menggunakan kandungan lokal, batasan atau kuota ekspor. Umumnya BIT juga mensyaratkan pimpinan perusahaan atau top manager adalah orang yang mereka pilih tanpa memperhatikan nasionalitasnya (Calvin A. Hamilton, \& Paula I. Rochwerger:2005:9)

BIT merupakan kombinasi yang unik dari hukum internasional publik dan hukum perdata internasional, mengijinkan investor mengajukan kasusnya ke forum arbitrase internasional terhadap negara berdaulat untuk kerugian yang muncul akibat tindakan negara tuan rumah. Dengan menandatangani $B I T$ berarti negara menyetujui untuk menundukkan dirirnya sendiri pada forum arbitrase yang dipilih oleh investor asing terhadap pelanggaran kewajiban BIT yang disangkakan non state adjudicator padanya (Alexis Blane, 2009:464)

Efek terpenting BIT adalah pihak yang dilindungi (investor), meskipun bukan pihak langsung pada BIT, diberikan hak langsung melawan negara yang dianggap merugikannya ke arbitrase internasional tanpa perlu persetujuan negara itu lagi. Dengan demikian, perjanjian investasi benar-benar menempatkan investor pada posisi yang sangat diunustungkan (Jose Luis Siqueiros, 1944:257). Pernyataan yang sama juga ditulis oleh Paul Michael Blyschak dalam artikelnya berjudul State consent, Investor Interests and the Future of Investment Arbitration: reanalyzing the Jurisdiction of Investor-State Tribunals in Hard cases (Paul Michael Blyschak :2010:109)

Sebagian besar ketentuan BIT berisikan kewajiban host state terhadap investor asing dan sangat sedikit sekali perhatian pada hak prerogatif yang menjadi bagian dari kedaulatan negara. Asimetri hubungan kedua belah pihak ini dapat dijelaskan dengan beberapa alasan. Pertama, home state tidak ingin menjadi respondent sebagai akibat tidak dilaksanakannya kewajiban dalam perjanjian di masa yang akan dating, sehingga kewajiban untuk home state hampir dikatakan tidak ada (Paul Michael Blyschak, 2010:110). Argumen kedua, negara pengekspor modal (home state) sangat menyadari bahwa BIT merupakan instrument utama perlindungan warga mereka di luar negeri sehingga dengan posisi tawar yang lebih besar mereka menuntut perlidungan seluas mungkin tanpa perlu ada kekhawatiran bahwa ketentuan dalam BIT akan digunakan host state untuk menyerang kepentingan warga mereka sendiri. Hasilnya adalah dorkumen yang perumusannya tidak jelas, berat sebelah (lopsided), dan hanya berisikan perlindungan investor. Tidak ada keseimbangan antara kepentingan kedua belah pihak, investor asing dan host state (Paul Michael Blyschak, 2010:110)

Ketidakjelasan aturan dalam perjanjian investasi dan penafsiran yang sangat luas dari arbitrase menjadikan putusan atau hasil penyelesaian sengketa investasi menjadi tidak dapat diprediksikan (unpredictable) (Joachim Karl:2012:37). ICSID yang menyatakan bahwa yurisdiksinya adalah semuaa sengketa hukum yang muncul dari investasi tanpa menjelaskan batasan investasi itu sendiri (Calvin A. Hamilton, \& Paula I Rochwerger, 2005:12).

Pengertian investasi asing menurut ensiklopedi hukum internasional publik adalah a transfer of funds or materials from one country (capital exporting country) to another country (host country) in return to a direct or indirect participation in the earnings of that enterprise. (Calvin A. Hamilton, \& Paula I Rochwerger:2005:12) Adapun definisi yang diberikan IMF lebih sempit karena tidak memasukkan investasi portofolio. IMF mendefinisikan investasi asing sebagai ..investment that is made to acquire a lasting interest in an enterprise operating in an economy other than that of an investor, the investor's purposes being to have an effective choice in the management of enterprise. (Calvin A. Hamilton, \& Paula I Rochwerger:2005:13) Adapun menurut Sornarajah, investasi asing mencakup transfer tangible or intangible assets from 
one country to another for the purpose of their use in that country to generate wealth under the total or partial control of the owner of the assets.(Sornarajah:2010:8)

Undang Undang Indonesia tidak menggunakan istilah investasi tetapi penanaman modal. Penanaman modal menurut Pasal 1 UU Nomor 25 tahun 2007 tentang Penanaman Modal adalah segala bentuk kegiatan menanam modal, baik oleh penanam modal dalam negeri maupun penanam modal asing untuk melakukan usaha di wilayah Negara Republik Indonesia. Adapun penanaman modal asing adalah kegiatan menanam modal untuk melaksanakan usaha di wilayah Negara Republik Indonesia yang dilakukan oleh penanam modal asing, baik yang menggunakan modal asing sepenuhnya maupun yang berpatungan dengan penanam modal dalam negeri

Adapun apabila dilihat dari evolusi perkembangan istilah investasi dalam hukum internasional, awalnya investasi hanyalah investasi langsung (foreign diretc investment). Hal ini berkaitan teori tanggung jawab negara dalam hukum internasional publik. Tanggung jawab negara akan muncul apabila negara tidak memperlakukan orang asing sesuai standar minimum. Standar perlakuan ini ditujukan pada aset fisik. Kehadiran secara fisik di negara tuan rumah dan adanya kerugian akibat tindakan tuan rumah menjadi dasar pengembangannya. Dalam hukum kebiasaan internasional pengaruh praktek Amerika Serikat yang menanamkan kewaaljiban ini pada negara-negara tetangganya, Amerika Latin, berpengaruh besar karena diikuti oleh negara-negara investor yang lain. Seiring dengan pertumbuhan investasi asing, hukum yang mengaturnya diperluas pada perlindungan tangible assets milik investor asing dari gangguan tuan rumah seperti pengambilalihan secara sewenang-wenang. Perkembangan selanjutnya perlindungan meluas pada intangible, hak-hak kontraktual seperti leases, mortgages, dan lien. Pasca kasus Barcelona Traction light case dimana ICJ memutuskan bahwa hanya negara tempat suatu perusahaan didaftarkan atau berbadan hukum yang memiliki legal standing di depan ICJ mewakili kepentingan perusahaan tersebut, bukan negara asal dari mayoritas pemegang saham, IcSld mengatasinya dengan mensyaratkan persetujuan negara tuan rumah untuk kriteria investodasi asing. Meskipun perusahaan tersebut berbadan hukum lokal tetapi untuk tujuan penyelesaian sengketa, atas persetujuan tuan rumah perusahaan tersebut dapat dianggap sebagai perusahaan asing. Adapun negaranegara pengekspor modal memutuskan untuk memasukkan perlindungan investor pemegang saham melalui BIT. Ditegaskan dalam hal ini bahwa saham yang dimaksud bukanlah invetasi portofolio tetapi saham yang ditanamkan langsung melalui BIT. Beberapa perjanjian seperti misalnya yang dibuat negara-negara ASEAN dengan tegas mengecualikan investasi portofolio dari ruang lingkup investasi asing. Perkembangan selanjutnya, perlindungan investasi asing semakin meluas termasuk di dalamnya hakhak intelektual seperti paten dan hak cipta (Sornarajah:2010: 11-13).

Dalam praktek di depan forum investment arbitration, istilah investment misalnya, seringkali ditafsirkan secara sangat luas dan terbuka (open ended definition) sehingga semua kategori aset, hak dan kepentingan investor tercakup di dalamnya (Sornarajah, 2010:8). Arbitrator melindungi semua hal yang bernilai ekonomi bagi investor tanpa pembatasan (Calvin A. Hamilton, \& Paula I. Rochwerger, 2005:3). Beberapa pembatasan investasi semestinya haruslah dilakukan, menurut Calvin A. Hamilton dan Paula I. Rochwerge investasi seharusnya tidak mencakup transaksi yang berulang kali terjadi seperti jual beli barang atau pinjaman komersial dalam jangka waktu yang singkat (short term commercial credits) (Calvin A. Hamilton, \& Paula I. Rochwerger:2005:3)

Ada lima karakteristik penting untuk investasi yaitu sebagai berikut. (Calvin A. Hamilton, \& Paula I. Rochwerger:2005:3)

a. Investasi harus memiliki durasi waktu tertentu.

b. Investasi mencakup aturan khusus tentang keuntungan dan pengembalian (profit and return).

c. Investasi umumnya mengandung elemen resiko bagi kedua belah pihak.

d. Investasi umumnya mengandung komitmen dan kontribuasi yang sangat substantial.

e. Investasi harus penting untuk pembangunan negara tuan rumah (host state development).

Adapun menurut AFM MAniruzzaman, sifat dan karakteristik investasi adalah sebagai berikut. (AFM Maniruzzaman, 2005:267). 
a. Dilakukan oleh pemerintah di satu sisi dengan perusahaan asing di sisi lain.

b. Pada umumnya dilandasi kontrak terkait eksploitasi sumber daya alam, pekerjaan publik (public work) seperti pembangunan jalan, waduk, jembatan, pelabuhan bandara, atau jasa pelayanan public (public service) seperti telekomunikasi, trarnsportasi, penyediaan air, listrik, manufacturing, agricultural activities, dalam jangka waktu yang tertentu.

c. Ada penyertaan modal atau instalasi permanen dalam jangka waktu tertentu yang ditentukan dalam perjanjian yang telah disepakati.

d. Hak yang tercipta tidak semata kontraktual tetapi juga hak kebendaan .

e. Adanya insentif yang dinikmmati investor asing seperti bebas dari bea cukai ekspor impor, berbgai macam pajal, fasilitas foreign exchange dan lain-lain.

f. Diatur oleh hukum publik dan perdata .

Beberapa ketentuan BIT yang tidak jelas berpotensi merugikan host state, antara lain (Paul Michael Blyschak :2010:19-20) :

a. kewajiban untuk memperlakukan investor asing secara fairly and equitable, termasuk di dalamnya memasukkan larangan denial of justice;

b. kewajiban untuk menyediakan full protection and security;

c. larangan expropriation tanpa kompensasi;

d. Kewajiban masing-masing negara pihak untuk menjamin bahwa hukum nasionalnya menyediakan sarana yang efektif penyampaian klaim dan pelaksanaan hak yang menghormati investasi, perjanjian investasi, dan pengesahan investasi

Permasalahan ketidakseimbangan perlindungan kepentingan kedua belah pihak tidak hanya dipicu oleh perumusan yang tidak jelas dalam perjanjian investasi tetapi juga didukung oleh peran arbitrase yang dalam banyak kasus menafsirkan secara sangat luas (broad definition and open-ended scope protection) ketentuan-ketentuan BIT sehingga berdampak pada terkikisnya kedaulatan negara tuan rumah (host state) (Stephan W Schill, 2006).

Di samping istilah investasi yang ditafsirkan dengan sangat luas dan merugikan negara tuan rumah yang umumnya negara berkembang dan terbelakang, beberapa contoh lain yang dapat dikemukakan misalnya terkait ketentuan full protection and security. Hampir semua BIT tidak memberikan definisi atau parameter yang jelas mengenai ketentuan ini. Pada umumnya arbitrase investasi akan menafsirkan bahwa full protection and security tidak sekedar keamanan fisik tetapi juga infrastruktur hukum untuk perlindungan investor asing secara efektif. Termasuk di sini adalah memberikan akses memperjuangkan keadilan baik di level domestik maupun internasional. Hak ini akan terganggu bila negara forum menerapkan doktrin imunitas negara absolut untuk menghambat akses ke pengadilan maupun hak untuk mendapat pelaksanaan (enforcement) atas suatu putusan arbitrase ginternasional. Alasan pengadilan umumnya adalah bahwa berperkara di pengadilan domestik tidaklah tanpa syarat (Paul Michael Blyschak, 2010:19-20).

Dalam kasus Mondev v United States, arbitrase NAFTA dihadapkan pada pertanyaan apakah imunitas negara yang diberikan berdasarkan hukum Massachussetts pada badan hukum publik tertentu akan melanggar kewajiban memberikan full protection and security yang dimuat dalam Pasal 11en05 (1) NAFTA. Menanggapi pertanyaan ini arbitrase menyetujui bahwa full protection and security secara umum akan terganggu ketika negara menerapkan doktrin imunitas negara untuk mencegah akses investor ke pengadilan domestik. Meskipun demikian, arbitrase menyatakan perlunya memahami secara detail alasan pemberian imunitas tersebut. Di samping itu, sangat penting dipahami bahwa hak akses ke pengadilan domestik tidaklah tanpa batas. Host state tetap memiliki kewenangan membatasi akses ke pengadilannya dengan mendasarkan pada alasan kepentingan public (public policy) (Paul Michael Blyschak, 2010:22).

Potensi pelanggaran kewajiban perjanjian investasi tidak hanya imunitas dari yurisdiksi tetapi juga imunitas dari eksekusi. Dalam kasus Deser Line v Yemen, dewan arbitrase menyatakan adanya pelanggaran terhadap ketentuan YemenOman BIT tentang kewajiban memberikan fair and equitable treatment juga larangan diskriminasi dan tindakan-tindakan yang tidak dapat dibenarkan secara hukum karena negara sudah memaksa investor untuk menerima ganti rugi yang jauh lebih kecil dari apa yang diputus oleh arbitrase. 
Kewajiban memberikan fair and equitable treatment serta non discriminatory and legally unjustified measures mensyaratkan negara melaksanakan putusan arbitrase yang mengadili sengketanya dengan pihak investor. Selanjutnya terkait kewajiban memberikan fair and equitable treatment. Pelanggaran terhadap kewajiban ini termasuk yang paling sering diajukan oleh pihak investor asing (Joachim Karl:2008:.235)

Dalam hukum kebiasaan internasional yang dikenal hanya perlindungan terhadap orang asing yang hanya melarang perlakuan yang tidak adil dan sewenang-wenang yang tidak dapat diterima dalam perspektif hukum internasional. Namun demikian dalam arbitrase investasi dikembangkan menjadi standar perlindungan yang sangat fleksibel dan terbuka sehingga tercakup di dalamnya lack of due process, pelanggaran terhadap legitimate expectation of the investor, ketiadaan good faith, ketiadaan transparansi, dan konsistensi aturan. Dalam kasus MTD Equity Sdn Bhd \& MTD Chile SA v Chile, fair and equitable treatment ditafsirkan sebagai tindakan yang paling kondusif untuk memenuhi tujuan BIT melindungi investasi dan menciptakan kondisi yang paling menguntungkan untuk investasi (MTD Equity Sdn Bhd \& MTD Chile SA v Chile, ICSID Case ARB/01/7, Award of 25ara May 2004)

Penafsiran yang sangat luas dan terbuka juga terjadi pada larangan expropriation tanpa kompensasi. Hukum kebiasaan internasional klasik menafsirkan expropriation sebagai expropriation secara langsung dan formal. Namun demikian, BIT dan arbitrase investasi menafsirkannya menjadi sangat luas. Dalam kasus Ethyl, tindakan pemerintah Canada yang melarang impor gasoline additive, MMT, yang dibutuhkan oleh investor dan mengakibatkan kerugian pada investor Amerika dikategorikan sebagai indirect expropriation (Joachim Karl:2008:235).

Selanjutnya dalam kasus Metalclad, arbitrase menyimpulkan bahwa tindakan pemerintah Mexico melarang penggunaan lahan sebagai underground landfill dan mengubah peruntukannya untuk area perlindungan hewan-hewan buas yang langka sebagai tindakan expropriation dan memberikan hak kompensasi bagi investor (Metalclad, Corporation v The United Mexican States, ICSID Case No ARB (AF)/97/1, award of 30 August 2000)
Dalam kasus Saipem v Bangladesh terkait expropriation without compensation, Icc telah memutuskan bahwa Saipem berhak atas ganti rugi sebesar 6 juta US. Namun demikian pengadilan nasional Bangladesh menolak melaksanakan putusan ini dan menyatakan bahwa putusan itu nullity and unenforceable (Joachim Karl:.2008:236).

Apa yang dilakukan pengadilan Bangladesh ini menurut ICSID dapat dikategorikan sebagai expropriation karena telah menghambat hak Saipem untuk mendapatkan haknya, terlebih putusan ini tidak dapat dilaksanakan di luar wilayah Bangladesh karena ketiadaan aset negara itu di luar negeri. Penolakan pelaksanaan putusan arbitrase berdasarkan nullifity and unenforceable ini pada dasarnya dapat disejajarkan dengan penolakan pelaksanaan putusan arbitrase berdasarkan penerapan doktrin imunitas negara. Berbagai kasus yang ada menggambarkan bahwa penerapan enforcement immunity dan immunity from jurisdiction dapat bersinggungan dengan berbagai standar dalam perjanjian investasi. Meskipun suatu putusan tidak menyebutkan secara langsung atau eksplisit mengenai diterapkkan doktrin imunitas negara, namun investor berhadapan dengan situasi yang sama dimana hak aksesnya ke pengadilan domestik ataupun haknya atas pelaksanaan putusan arbitrase tidak dapat diperolehnya karena tindakan-tindakan yang dilakukan oleh pihak eksekutif, legislative maupun yudikatif host state. Dalam perspektif ekonomi tindakan-tindakan itu memberikan efek yang equivalent dengan penggunaan doktrin imunitas negara untuk menghambat yurisdiksi atau pelaksanaan suatu putusan arbitrase. Hal ini harus dianggap sama dengan tindakan denial justice yang merupakan hambatan pelaksaan suatu putusan abritrase.

Jumlah ganti rugi yang dibebankan pada negara berkembang dan terbelakang pada putusan arbitrase komersial internasional juga sering dianggap tidak rasional. Dalam kasus Guyana melawan v Big Food group (BFg) misalnya, negara miskin dari Amerika Selatan itu diwajibkan membayar ganti rugi pada perusahaan transnasional dari Inggris sebesar 12 juta poundsterling. Jumlah ini lebih dari dua kali lipat gross National product Guyana. Ketidakadilan dirasakan bahwa ganti rugi itu untuk membayar hutang Guyana akibat menasionalisasi perusahaan gula BFK yang 
telah dibayar 6 juta poundsterling, belum lunas terbayarkan karena krisis keuangan dan adanya ancaman bahaya kelaparan di negara tersebut. Namun demikian atas putusan arbitrase, hutang membengkak menjadi 12 juta poundsterling. Kasus serupa juga menimpa sekitar 21 negara miskin lainnya (Calvin A. Hamilton, \& Paula lad. Rochwerge, 2005:6)

Ketidakseimbangan dan ketidakadilan baik dalam perjanjian investasi maupun proses arbitrase yang terlalu berpihak pada kepentingan investor asing sangatlah dirasakan oleh negara berkembang sebagai negara pengimpor modal. Hal ini menjadi salah satu pemicu negara berkembang tidak mau dengan sukarela melaksanakan putusan arbitrase komersial internasional yang dianggapnya tidak memberikan rasa keadilan. Penggunaan arbitrase komersial internasional baik yang berdasarkan kontrak maupun perjanjian investasi memang menjadi tujuan negara maju, yang dalam perspektif negara berkembang hal ini dikarenakan arbitrase tersebut telah menjadi industri komersial tersendiri yang sangat menguntungkan bagi negara maju. Data menunjukkan bahwa Tahun 1992 hanya ada 11 International commercial Arbitration dengan 1137 kasus. Pada tahun 2007 menjadi 30 arbitrase dengan 3280 kasus. (http://papers.ssrn.com/sol3/ papers.cfm?abstract id=986507).

Sebagaimana diketahui arbitrase komersial internasional ini pada umumnya berada di wilayah negara maju sehingga akan memberikan keuntungan pada mereka karena beaya administrasi institusi, beaya arbitrator, saksi ahli, gaji karyawan, dan pungutan-pungutan lain akan masuk pada mereka. Pengacarapun umumnya juga berasal dari negara maju karena sering negara berkembang kurang percaya diri untuk menggunakan pengacara dari negara mereka sendiri yang dianggap kurang memahami seluk beluk beracara di arbitrase intrenasional. Hal ini dapat dipahami karena sistem yang ada di arbitrase komersial internasional memadukan sistem hukum civil law dan common law dari negara Eropa Barat dan Amerika Utara (Dough Sperry, 2010 : 3655). Dominasi dalam hal hukum, akademisi maupun praktisi yang berasal dari negara maju dianggap sebagai mafia arbitrase oleh negara-negara berkembang karena jarang sekali negara berkembang menang dalam kasus melawan investor asing di depan arbitrase komersial internasional (Leslie Mazoch, 2007).

Pendapat senada juga disampaikan oleh Toby Landau dalam tulisannya berjudul The day Before Tomorrow: Future developments in International Arbitration, yang disampaikan dalam pidato yang disampaikan di Clayton Utz/ University of Sydney International Arbitration Lecture 2009, Banco Court, Sydney, 21 October 2009 (Dough Sperry, 2010 : 365-366).

Dari paparan di atas dapat disimpulkan bahwa ada beberapa faktor penyebab negara berkembang dan terbelakang senantiasa kalah di forum investment arbitration. pertama, keberadaan BIT yang isinya sangat berpihak pada kepentingan negara pengekspor modal dan sebaliknya sangat merugikan kepentingan negara pengimpor modal. Hal ini dapat terjadi karena adanya ketidakseimbangan dalam bargaining power saat pembuatan BIT. Kedua, tidak jelasnya aturan-aturan yang ada dalam BIT. Istilahistilah penting dalam $B I T$ tidak diberikan definisi atau penjelasam sehingga menimbulkan multitafsir. Ketiga, investment arbitration telah menjadi industri tersendiri bagi negara-negara maju. Sistem hukum negara-negara maju sangat mendominasi proses persidangan di depan forum investment arbitration. Para arbitrator yang hampir semua berasal dari negara maju akan menafsirkan ketentuanketentuan secara open ended interpretation, sesuai kepentingan negara mereka dan pada akhirnya sangat merugikan kepentingan negara pengimpor modal yang umummnya negara berkebang dan terbelakang.

\section{d. Penutup}

1. Simpulan

Berdasarkan hasil penenelitian dan pembahasan, dapat disimoulkan sebagai berikut.

a. Investment Arbitration adalah bagian dari arbitrase komersial internasional yang menangani kasus sengketa investasi asing. Para pihak dalam arbitrase ini adalah negara tuan rumah dengan investor asing. Penyelenggaraan arbitrase ini tidak hanya berdasarkan kontrak antara para pihak yang bersengketa tetapi juga didasari oleh ketentuan hukum internasional publik khususnya Bilateral Investment Treaty (BIT). 
b. Ada beberapa faktor penyebab negara berkembang dan terbelakang senantiasa kalah di forum investment arbitration, yaitu :

1) keberadaan $B I T$ yang isinya sangat berpihak pada kepentingan negara pengekspor modal dan sebaliknya sangat merugikan kepentingan negara pengimpor modal.

2) tidak jelasnya aturan-aturan dalam $B I T$;

3) investment arbitration telah menjadi industri tersendiri bagi negaranegara maju.
2. Saran

Negara berkembang dan terbelakang yang umumnya merupakan negara pengimpor modal harus cermat dan memiliki posisi tawar yang baik saat menyusun BIT. Tanpa posisi tawar yang baik BIT akan memojokkan posisi negara pengimpor modal sehingga harus selalu menerima kekalahan di depan forum investment arbitration. Posisi tawar yang baik hanya akan diperoleh apabila negara memiliki independency, tidak memiliki kebergantungan yang besar pada negara pengekspor modal dalam segala bidang seperti ekonomi, politik, juga pertahanan dan keamanan.

\section{daftar Pustaka}

Anderson, Sarah \& Grusky, Sara .2007. "Food \& Water Watch, challenging corporate Investor rule: How the World Bank's Investment court, Free Trade Agreements, and Bilateral Investment Treaties Have Unleashed a New Era of corporate power and What to do About It". http://www.ips-dc.org/ reports/070430 challengingcorporateinvestorrule. pdf

Anonim. 2008. Putusan pengadilan distrik Texas tahun 2002 dalam kasus Karaha Bodas Company LLC Petitioner v Perusahaan Pertambangan Minyak dan Gas bumi Negara, respondent No. Clv.A.H 01-0634. (264 F.Supp.2d 470), Putusan pengadilan distrik New York tahun 2004 No. M-18-302 (TPG) (305 F.Supp.2d 304), Court of Final Appeal Final Appeal No 6 of 2008 (Civil) CFA FACV 6/2008 (2008 WL 4928699 (CFA). [2008] HKEC 2063)

2009. U.N. conference on Trade and dev., Latest developments in Investor-State dispute Settlement, IIA MONITOrNo. 4, 1, U.N. doc. UNcTAd/WEB/ITE/IIT/2005/2 . http://www.unctad. org/en/docs/webiteiit20092

. 2004. MTd Equity Sdn Bhd \& MTd chile SA v chile, IcSId case ArB/01/7, Award of 25 May 2004

2000. Metalclad, corporation v The United Mexican States, IcSId case No ArB (AF)/97/1, award of 30 August 2000.

Bernasconi, Nathalie \& Osterwalder. 2005. "Who Wins and Who Loses in Investment Arbitration? Are Investors and Host States on a Level playing Field?”. Journal of World Investment and Trade, 6 J. World Inv. \& Trade 69

Blane, Alexis. 2009. "Sovereign Immunity as a Bar to The Execution of International Arbitral Awards". 41 N.Y.U. J. Int'I L. \& Pol. p. $453-488$

Blyschak,, Paul Michael. 2010. "State consent, Investor Interests and the Future of Investment Arbitration: reanalyzing the Jurisdiction of Investor-State Tribunals in Hard cases”. Asper Review of International Business and Trade Law, 9 Asper Rev. Int'l Bus. \& Trade L. 99

Dunbar, Damon \& Nikeima, Henrique Suzy. 2009. “do Bilateral Investment Treaties Lead to More Foreign Investment?". Investment Treaty News. . http:// www.investmenttreaty news.org/cms/news/ archive/2009/04/30/do-bilateral-investment-treatieslead-to more-foreign-investment.aspx.

Franck, Susan D. 2007. "Empirically Evaluating claims About Investment treaty Arbitration”. 86 N.C. L. Rev. 1.

Hamilton, Calvin A, \& Rochwerger, Paula I. winter 2005. "Trade and Investment: Foreign direct Investment Through Bilateral and Multilateral Treaties”. New York International Law Review, 18 N.Y. Int'I L. Rev. 1. 
http://hukumonline.com/berita/baca/hol22092/pertamina-ajukan-pembatalan-putusan-arbitrase-icctp:// hukumonline.com/berita/baca/hol22092/pertamina-ajukan-pembatalan-putusan-arbitrase-icc. pertamina Ajukan pembatalan putusan ICC.

Huala Adolf. 1991. Arbitrase Komersial Internasional. Jakarta : Rajawali Press

Juwana, Hikmahanto, "Pembatalan Putusan Arbitrase Internasional oleh Pengadilan Nasional", dalam Jurnal Hukum Bisnis, Vol.21 Oktober-November 2002.

Kantaadmadja, Mieke Komar. 2011. "Pengakuan dan Pelaksanaan Putusan Arbitrase Internasional di Indonesia (studi kasus)". Makalah. Disampaikan dalam Seminar recognition and Enforcement of International Arbitration Awards under The New York convention 1958 and Indonesia Arbitration Law . Yogyakarta: Fakultas Hukum Universitas Gadjah Mada

Karl, Joachim, "International Investment Arbitration: A Threat to State Sovereignty?", dalam Shan, Wenhua, Simons, Penelope, and Singh, Dalvinder (editor), (2008), Redefining Sovereignty in International Economic Law, , Studies in International Trade Law: volume 7, Hart Publishing c/o International Specialized Book Services. USA, hlm.225-245

Lew, Julian DW, (ed) 1987, contemporary problems in International Arbitration, Martinus Nijhoff Publishers

Maniruzzaman, AFM. 2005. "The relevance of public International Law in Arbitrations concerning International Economic development Agre2ements An Appraisal of some Fundamental Aspects". The Journal of World Investment \& Trade", Jwit62.

Mazoch, Leslie. 2007, April 30. "chavez Takes cool View Toward OAS, Says Latin America Better Off Without World Bank". Huffington Post. http:// www.huffingtonpost.com/ huff-wires/20070430/ la-gen-venezuela-leftist-alternative [13 October 2012]

Mekay, Emad. 2004. "poorer Nations pay dearly for Investment deals". Global Pol'y F. http://www. globalpolicy.igc.org/socecon/trade/unctad/2004/1129invest.htm. [22 desember 2012].

Odumosu,, Ibironke T. 2007. "The Law and politics of Engaging resistance in Investment dispute Settlement". Penn State International Law Review, 26 Penn St. Int'I L.Rev. 251

Schill,, Stephan W. 2006. "Fair and Equitable Treatment under Investment Treaties as an Embodiment of the rule of Law". IILJ Working Paper 2006/6 (Global Administrative Law Series), Institute for International Law and Justice .http://www.iilj.org/ publications/2006-6Schill.asp., 12 dsem.

Shihata, Ibrahim F.I. 1993. Toward a greater depoliticization of Investment disputes: The roles of IcSId and MIgA, for a discussion of the calvo clause in the IcS/d context . http://www.miga.org/ documents/investing with confidence eBook.pdf. [15 September 2011].

Siqueiros, Jose Luis. 1944. "Bilateral Investment Treaties on the reciprocal protection of Foreign investment". California International Law Journal, 24 Cal. Int'I L.J. 255.

Sperry, Doug. 2010. "The Impact of International commercial Arbitration on developing Nations: Has the Emergence of the International private Justice Market Narrowed the gap between developed and developing parties?". 40 HKLJ 361

Sornarajah, M. 2010. The International Law of Foreign Investment. $3^{\text {rd }}$ edition. Cambridge University Press.

Trakman, Leon E. tt. "Legal Traditions' and International commercial Arbitration". American Review of International Arbitration.13. http://papers.ssrn.com/sol3/papers.cfm? abstract id=986507. [15 oktober 2009].

Walde, Thomas. 1998, Oct. "Investment Arbitration Under the Energy charter Treaty: From dispute Settlement to Treaty Implementation 14". http:// www.dundee.ac.uk/ cepmlp/ journal/ html/vol1/ article1-10.pdf. [22 Desember 2012].

W Schill, Stephen. 2010. "crafting the international economic order: the public function of investment treaty arbitration and its significance for the role of the arbitrator". L.J.I.L. 23(2), 401-430. 